\title{
Comparative investigation of heavy metal, trace, and macro element contents in commercially valuable fish species harvested off from the Persian Gulf
}

\author{
Dariush Ranjbar Vakil Abadi • Sina Dobaradaran • \\ Iraj Nabipour • Xolelwa Lamani • Masoumeh Ravanipour • \\ Rahim Tahmasebi $\cdot$ Shahrokh Nazmara
}

Received: 3 September 2014 / Accepted: 10 November 2014 / Published online: 22 November 2014

(C) Springer-Verlag Berlin Heidelberg 2014

\begin{abstract}
This study was performed to determine the differences between two commercial species of fish harvested off near the Kharg Island (one of the largest oil terminals in the world) in the Persian Gulf in terms of toxic metals, macro, and trace elements. Samples were analyzed using inductively coupled plasma-optical emission spectrometry (ICP-OES). The results showed that $\mathrm{Ca}, \mathrm{Li}, \mathrm{Mg}, \mathrm{P}, \mathrm{Se}, \mathrm{Sn}, \mathrm{Sr}$, and $\mathrm{Zn}$ concentrations were significantly different between the skin and muscle tissues of Scomberomorus guttatus but with the exception of $\mathrm{P}$, there was no significant difference between element levels in the skin and muscle tissues of Otolithes ruber. The $S$. guttatus contained significantly higher levels
\end{abstract}

Responsible editor: Philippe Garrigues

D. R. V. Abadi · S. Dobaradaran · M. Ravanipour · R. Tahmasebi Department of Environmental Health Engineering, Faculty of Health, Bushehr University of Medical Sciences, Rishehr Street, Bushehr P.O. Box 7518759577, Iran

S. Dobaradaran

Systems Environmental Health, Oil, Gas and Energy Research Center, Bushehr University of Medical Sciences, Bushehr, Iran

S. Dobaradaran $(\bowtie)$

The Persian Gulf Marine Biotechnology Research Center, Boostan 19 Alley, Imam Khomeini Street, Bushehr 7514763448, Iran e-mail: sina_dobaradaran@yahoo.com

I. Nabipour

Department of Infectious Diseases, The Persian Gulf Tropical Medicine Research, Boostan 19 Alley, Imam Khomeini Street, Bushehr 7514763448, Iran

\section{Lamani}

Instrumental Analytical Chemistry, University Duisburg-Essen, 45141 Essen, Germany

\section{S. Nazmara}

School of Public Health, Tehran University of Medical Sciences, Tehran P.O. Box 6446, Iran of As, Sn, Se, and P in the muscle tissue and $\mathrm{Zn}$ in the skin tissue compared to the muscle and skin tissues of Otolithes ruber. The estimated daily intake of the toxic elements including $\mathrm{As}, \mathrm{Cd}, \mathrm{Sb}, \mathrm{Pb}$, and $\mathrm{Sn}$ via consumption of these fish were below the established guidelines but due to the potential contamination by oil activities near the island, continuous and permanent monitoring in this region is highly recommended.

Keywords Scomberomorusguttatus $\cdot$ Otolithes ruber · Heavy metals $\cdot$ Trace elements $\cdot$ Persian Gulf

\section{Introduction}

There is an increasing concern about the quality of foods in some parts of the world. The measurement of toxic elements in different foods has prompted researches to study the toxicological effects of these elements in food. Heavy metals (HMs) are considered as one of the most critical contaminants of the aquatic ecosystem because of their potential to enter water bodies and also their bioaccumulation and biomagnification in the food chain (Olojo et al. 2005). Fish are commonly situated at the top of the food chain and are considered as a susceptible aquatic organism to toxics present in water (Alibabic et al. 2007). Moreover, the increasing importance of aquatic food including fish as protein sources extended the focus toward aquatic ecosystem. So, in recent years, much attention has been focused on the levels of HMs in fish and other food to determine the hazard effects of HMs for human health. HMs can enter into water bodies and aquatic ecosystems through drainage, atmosphere, soil erosion, and all human activities by different ways. Contaminants including HMs enter fish body through several main routes: via gills, non food particles, skin, and oral consumption of 
water. These metals concentrate at different contents in organs of fish body. Some metals such as iron, copper, zinc, and manganese are essential for biological systems such as enzymatic activities, whereas, other HMs like arsenic, lead, cadmium, and tin have no known important role in living organs and are toxic even in trace amounts (Fernandes et al. 2008). Essential metals must be taken up from water, food, or sediment by fish for its normal metabolism (Canli and Atli 2003). However, these metals can also have adverse and toxic effects at high concentration (Tüzen 2003). Heavy metal levels of fish body have been broadly studied (Canli and Atli 2003; Fernandes et al. 2008; Mansour and Sidky 2002; Tüzen 2003) and its distribution varies between fish species (Kagi and Schaffer 1988).

Two commercial important species of fish in the Persian Gulf are including Scomberomorus guttatus (Indo-Pacific king mackerel) and Otolithes ruber (tiger tooth croaker) fish. S. guttatus is found in the Indo-West Pacific, Persian Gulf, India, and Sri Lanka to Southeast Asia, north of Hong Kong and Wakasa Bay, Sea of Japan, and Gulf of Thailand. They are a pelagic species and tending to migrate locally around the beach and sometimes entering turbid estuarine areas. Juveniles of $S$. guttatus feed mainly on teleosts, especially anchovies, while adults prey mainly on fish with small quantities of squids and crustaceans. O. ruber is found in the West Indian Ocean from the east to Queen's lands of Australia and Japan except the Red Sea, across the Persian Gulf coastal area, and Oman Sea. They live in the marine coastal area water and mostly on the muddy surfaces and rivers mouths (Collette and Nauen

Fig. 1 Location of sample points near the Kharg Island in the Persian Gulf
1983; Fischer and Bianchi 1984). Food of O. ruber consists of such crustaceans as shrimp and other invertebrates. Juveniles of $\mathrm{O}$. ruber feed mainly on zoobenthos while adults prey mainly on small fish and crustaceans (especially shrimp).

Fish muscle tissue is not always a suitable indicator of the whole fish body contamination and, therefore, it is important to examine other tissues, such as skin. To our knowledge, $S$. guttatus and $O$. ruber fish in the Persian Gulf have not been examined in detail for different content of heavy metals, macro, and trace elements in their skin and muscle tissues. As fish from the Persian Gulf serve as the main source of protein for people living in this region (including Iran in the north and Arabic countries in the south of the Persian Gulf), we measured the heavy metals, macro, and trace elements in the skin, and muscle tissues of these two species of fish that harvested off near the Kharg island, one of the largest oil terminals in the world. In this study we report the $\mathrm{Ag}, \mathrm{Al}$, As, B, Ca, Cd, Cu, Fe, Li, Mg, Mn, Na, Ni, P, Pb, Sb, Se, Si, $\mathrm{Sn}, \mathrm{Sr}$, and $\mathrm{Zn}$ concentrations of the skin and muscle tissues of the mentioned fish to monitoring contaminants accumulation in the edible tissues as well as the nutrition values of these fish.

\section{Materials and methods}

\section{Sample collection and preparation}

Fish samples including $S$. guttatus and $O$. ruber were harvested and collected near the Kharg island, one of the largest oil terminals in the world, in the Bushehr province. Kharg Island

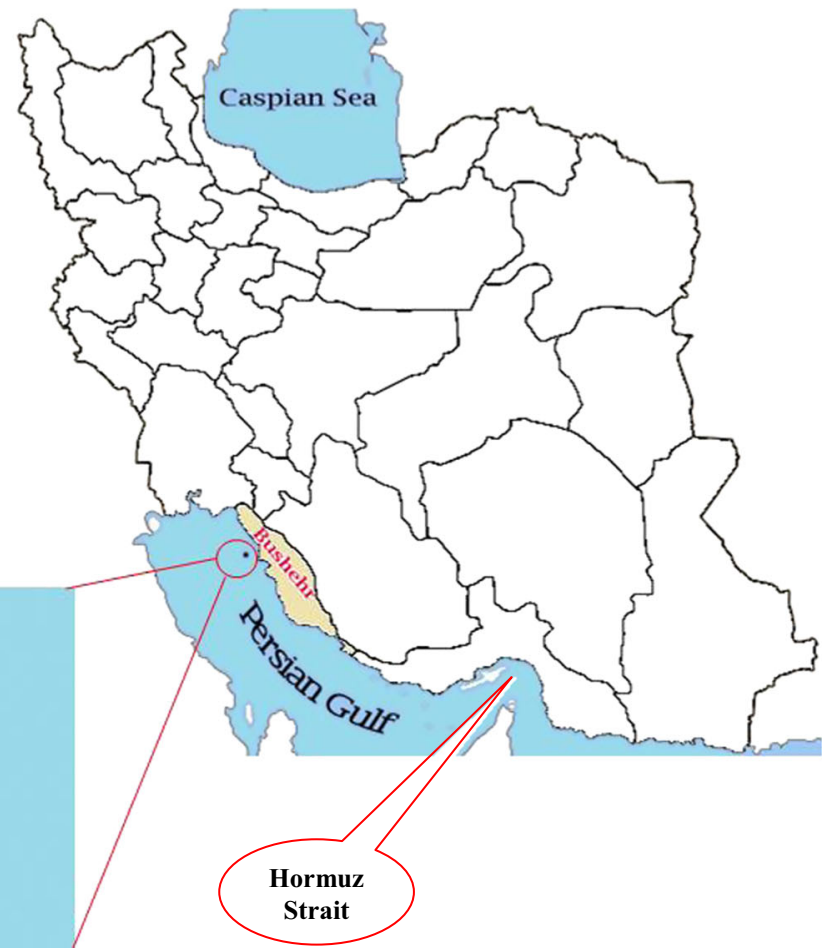


is located $25 \mathrm{~km}$ off the coast in the Bushehr province of Iran and $483 \mathrm{~km}$ in the northwest of the Hormuz Strait (Fig. 1). About $20 \%$ of the world's petroleum, and nearly $35 \%$ of the petroleum traded by sea, passes through the Hormuz Strait, making it a highly important strategic location for international oil trade. This island provides a sea port for the export of the Iranian oil. The mean weight and length $($ mean \pm SD) of fish were $905 \pm 25.4 \mathrm{~g}$ and $39.3 \pm 4.3 \mathrm{~cm}$ for $S$. guttatus and $965 \pm$ $31.8 \mathrm{~g}$ and $42.1 \pm 5.1 \mathrm{~cm}$ for $O$. ruber. The fish were brought to the laboratory and washed with distilled water. Muscle and skin were dried, homogenized, and ground first with a meat grinder and later, with a mortar and pestle to a fine powder.

\section{Reagents}

$\mathrm{HNO}_{3}(65 \%)$ and $\mathrm{H}_{2} \mathrm{O}_{2}(30 \%)$ were of supra pure quality (Merck, Darmstadt, Germany). All the plastic and glassware was cleaned by soaking in dilute nitric acid and rinsed with distilled water before use. All solutions were prepared using ultrapure water (resistivity $18.2 \mathrm{M} \Omega \mathrm{cm}$ ).

\section{Analytical procedures}

A weighed sample $(1 \mathrm{~g})$ of dry skin and muscle powder was mixed with $4 \mathrm{ml} 30 \%$ of $\mathrm{H}_{2} \mathrm{O}_{2}$ and $8 \mathrm{ml}$ of $65 \%$ $\mathrm{HNO}_{3}$ in a Teflon container and the samples were digested by boiling until all the contents dissolved. After cooling to room laboratory temperature, the solution was filtered through filter (a $0.45-\mu \mathrm{m}$ nitrocellulose membrane filter) and transferred to an acid-washed volumetric flask $(25 \mathrm{ml})$ and ultrapure water was added to bring the final sample volume up to $25 \mathrm{ml}$. Blank digest was also performed in the same way.

Analysis of the elements including Ag, Al, As, B, Ca, Cd, $\mathrm{Cu}, \mathrm{Fe}, \mathrm{Li}, \mathrm{Mg}, \mathrm{Mn}, \mathrm{Na}, \mathrm{Ni}, \mathrm{P}, \mathrm{Pb}, \mathrm{Sb}, \mathrm{Se}, \mathrm{Si}, \mathrm{Sn}, \mathrm{Sr}$, and $\mathrm{Zn}$ was carried out by inductively coupled plasma optical spectrometry (ICP-OES). In Table 1, details of the instrumental operating conditions are presented. All heavy metal, macro, and trace element concentrations were expressed as micrograms per gram wet weight $(w w)$. Statistical analysis of data was carried out with the statistical package for the social sciences (SPSS) and independent sample $t$ test and Pearson's correlation coefficient were performed for statistical significant differences. Differences in mean values were accepted as being significant if $P<0.05$.

\section{Results and discussion}

The heavy metal, macro, and trace element concentrations in the muscle and skin tissue samples of the S. guttatus and the O. ruber are presented in Table 2.
Table 1 ICP-OES instrumental operating details

\begin{tabular}{|c|c|}
\hline \multicolumn{2}{|l|}{ Parameter } \\
\hline Company, model & $\begin{array}{l}\text { SPECTRO (Germany), } \\
\text { Spectro arcos }\end{array}$ \\
\hline RF generator power (W) & 1400 \\
\hline Frequency of RF generator (MHz) & 27.12 MHz \\
\hline Type of detector & Charge coupled devices (CCD) \\
\hline Torch type & Flared-end EOP torch $2.5 \mathrm{~mm}$ \\
\hline Plasma, auxiliary, and nebulizer gas & High purity (99.99 \%) argon \\
\hline Plasma gas flow rate (1/min) & 14.5 \\
\hline Auxiliary gas flow rate (1/min) & 0.9 \\
\hline Nebulizer gas flow rate (1/min) & 0.85 \\
\hline Sample uptake time (s) & 240 total \\
\hline Delay time of (s) & - \\
\hline Rinse time of (s) & 45 \\
\hline Initial stabilization time (s) & Preflush:45 \\
\hline Time between replicate analysis (s) & - \\
\hline Measurement replicate & 3 \\
\hline Pump rate & 30 RPM \\
\hline Element $(\lambda / \mathrm{nm})$ & Ag 328.068; Al 396.152 \\
\hline & As $189.042 ;$ B 249.773 \\
\hline & $\mathrm{Ca} 422.673 ; \mathrm{Cd} 228.802$ \\
\hline & $\mathrm{Cu} 324.754 ; \mathrm{Fe} 259.941$ \\
\hline & Li 670.780; Mg 279.553 \\
\hline & Mn 257.611; Na 589.592 \\
\hline & Ni 231.604; P 177.495 \\
\hline & $\mathrm{Pb} 283.305 ; \mathrm{Sb} 206.833$ \\
\hline & Se 196.090; Si 251.611 \\
\hline & Sr 346.446; Sn 189.991 \\
\hline & $\mathrm{Zn} 268.416$ \\
\hline
\end{tabular}

As shown in Fig. 2a, b, the orders of heavy metal, macro, and trace element concentrations of $O$. ruber were $\mathrm{P}>\mathrm{Na}>$ $\mathrm{Ca}>\mathrm{Mg}>\mathrm{Zn}>\mathrm{Sr}>\mathrm{Al}>\mathrm{Fe}>\mathrm{Si}>\mathrm{Cu}>\mathrm{Se}>\mathrm{Ag}>\mathrm{B}>\mathrm{As}>$ $\mathrm{Ni}>\mathrm{Cd}>\mathrm{Pb}>\mathrm{Mn}>\mathrm{Sb}>\mathrm{Li}>\mathrm{Sn}$ in the muscle and $\mathrm{P}>\mathrm{Ca}>$ $\mathrm{Na}>\mathrm{Mg}>\mathrm{Zn}>\mathrm{Sr}>\mathrm{Fe}>\mathrm{Al}>\mathrm{Si}>\mathrm{Mn}>\mathrm{Se}>\mathrm{Cu}>\mathrm{As}>\mathrm{Ni}>$ $\mathrm{B}>\mathrm{Ag}>\mathrm{Pb}>\mathrm{Sb}>\mathrm{Li}>\mathrm{Sn}$ in the skin.

In the case of $S$. guttatus, the orders of heavy metal, macro, and trace element levels of fish were $\mathrm{P}>\mathrm{Mg}>$ $\mathrm{Na}>\mathrm{Ca}>\mathrm{Zn}>\mathrm{Si}>\mathrm{Fe}>\mathrm{Sr}>\mathrm{As}>\mathrm{Se}>\mathrm{Al}>\mathrm{Cu}>$ $\mathrm{Mn}>\mathrm{B}>\mathrm{Pb}>\mathrm{Ni}>\mathrm{Sn}>\mathrm{Cd}>\mathrm{Sb}>\mathrm{Ag}>\mathrm{Li}$ in the muscle and $\mathrm{Ca}>\mathrm{P}>\mathrm{Na}>\mathrm{Mg}>\mathrm{Zn}>\mathrm{Sr}>\mathrm{Al}>\mathrm{Fe}>$ $\mathrm{Si}>\mathrm{Cu}>\mathrm{As}>\mathrm{Mn}>\mathrm{B}>\mathrm{Ag}>\mathrm{Se}>\mathrm{Ni}>\mathrm{Cd}>\mathrm{Sb}>$ $\mathrm{Li}>\mathrm{Sn}$ in the skin (Fig. 2c, d). Recently, considerable studies have been done to determine the distribution of heavy metals, macro, and trace elements in different aquatic ecosystems and different parts of fish body (Dobaradaran et al. 2010, 2011; Dural et al. 2007; Fallah et al. 2011; Mansour and Sidky 2002; Mendil et al. 2010; Saei-Dehkordi and Fallah 2011; Santos et al. 2013; Tüzen 2003; Tuzen et al. 2009; Yilmaz 
Table 2 Mean and range concentration of the elements in the muscle and skin of the fish $(\mu \mathrm{g} / \mathrm{g} /$ wet weight; values are mean $\pm \mathrm{SD}$, sample number for each parameter $=7$ )

\begin{tabular}{|c|c|c|c|c|}
\hline \multirow[t]{2}{*}{ Elements } & \multicolumn{2}{|l|}{ O. ruber } & \multicolumn{2}{|l|}{ S. guttatus } \\
\hline & Muscle & Skin & Muscle & Skin \\
\hline \multirow[t]{2}{*}{$\mathrm{Ag}$} & $0.43 \pm 0.40$ & $0.36 \pm 0.46$ & $0.09 \pm 0.08$ & $0.54 \pm 0.66$ \\
\hline & $(0.05-0.93)$ & $(0.01-0.97)$ & $(0.01-0.24)$ & $(0.03-1.67)$ \\
\hline \multirow[t]{2}{*}{$\mathrm{Al}$} & $4.01 \pm 3.49$ & $3.41 \pm 1.58$ & $0.99 \pm 0.26$ & $7.14 \pm 5.94$ \\
\hline & $(0.47-7.52)$ & $(0.28-4.48)$ & $(0.74-1.25)$ & $(0.79-17.85)$ \\
\hline \multirow[t]{2}{*}{ As } & $0.36 \pm 0.08$ & $0.46 \pm 0.18$ & $1.17 \pm 0.34$ & $0.80 \pm 0.35$ \\
\hline & $(0.27-0.46)$ & $(0.31-0.76)$ & $(0.83-1.63)$ & $(0.43-1.30)$ \\
\hline \multirow[t]{2}{*}{$\mathrm{Fe}$} & $2.34 \pm 0.46$ & $3.67 \pm 1.87$ & $2.93 \pm 1.43$ & $4.80 \pm 2.35$ \\
\hline & $(1.79-2.84)$ & $(1.75-6.44)$ & $(1.37-5.29)$ & $(2.54-8.82)$ \\
\hline \multirow[t]{2}{*}{$\mathrm{Mn}$} & $0.18 \pm 0.16$ & $0.74 \pm 1.00$ & $0.55 \pm 0.43$ & $0.57 \pm 0.21$ \\
\hline & $(0.03-0.40)$ & $(0.20-2.77)$ & $(0.05-1.09)$ & $(0.43-0.95)$ \\
\hline \multirow[t]{2}{*}{$\mathrm{Sb}$} & $0.11 \pm 0.02$ & $0.14 \pm 0.03$ & $0.13 \pm 0.05$ & $0.10 \pm 0.02$ \\
\hline & $(0.09-0.13)$ & $(0.11-0.19)$ & $(0.08-0.21)$ & $(0.07-0.14)$ \\
\hline \multirow[t]{2}{*}{ Sn } & $0.04 \pm 0.00$ & $0.04 \pm 0.01$ & $0.23 \pm 0.21$ & $0.04 \pm 0.01$ \\
\hline & $(0.03-0.04)$ & $(0.02-0.04)$ & $(0.04-0.50)$ & $(0.02-0.04)$ \\
\hline \multirow[t]{2}{*}{$\mathrm{Zn}$} & $7.04 \pm 3.15$ & $14.92 \pm 10.78$ & $18.37 \pm 23.08$ & $53.15 \pm 21.68$ \\
\hline & $(3.25-10.15)$ & $(5.54-33.20)$ & $(4.27-64.09)$ & $(27.91-78.81)$ \\
\hline \multirow[t]{2}{*}{ B } & $0.38 \pm 0.17$ & $0.40 \pm 0.23$ & $0.46 \pm 0.21$ & $0.55 \pm 0.17$ \\
\hline & $(0.18-0.63)$ & $(0.23-0.86)$ & $(0.22-0.75)$ & $(0.43-0.88)$ \\
\hline \multirow[t]{2}{*}{$\mathrm{Ca}$} & $262.51 \pm 153.22$ & $406.40 \pm 233.58$ & $237.23 \pm 138.42$ & $631.28 \pm 173.56$ \\
\hline & $(99.26-510.72)$ & $(150.49-613.5)$ & $(110.57-411.4)$ & $(357.5-791.7)$ \\
\hline \multirow[t]{2}{*}{$\mathrm{Li}$} & $0.06 \pm 0.02$ & $0.08 \pm 0.03$ & $0.06 \pm 0.02$ & $0.10 \pm 0.01$ \\
\hline & $(0.04-0.09)$ & $(0.05-0.12)$ & $(0.03-0.10)$ & $(0.09-0.12)$ \\
\hline \multirow[t]{2}{*}{$\mathrm{Mg}$} & $184.16 \pm 29.80$ & $132.35 \pm 53.20$ & $265.50 \pm 96.97$ & $121.57 \pm 26.97$ \\
\hline & (146.89-229.82) & (84.3-198.84) & $(152.6-440.8)$ & $(74-147.31)$ \\
\hline \multirow[t]{2}{*}{$\mathrm{Na}$} & $329.61 \pm 102.00$ & $279.87 \pm 88.52$ & $261.26 \pm 154.76$ & $212.05 \pm 82.15$ \\
\hline & $(224.71-490.38)$ & $(148.68-424.0)$ & $(109.96-521.3)$ & $(116.82-307.5)$ \\
\hline \multirow[t]{2}{*}{$\mathrm{P}$} & $847.52 \pm 80.13$ & $473.75 \pm 302.18$ & $1339.68 \pm 446.60$ & $478.75 \pm 123.66$ \\
\hline & (765.77-1000.8) & $(174.92-863.7)$ & $(745-2121.5)$ & $(261.30-606.57)$ \\
\hline \multirow[t]{2}{*}{$\mathrm{Se}$} & $0.67 \pm 0.09$ & $0.67 \pm 0.13$ & $1.04 \pm 0.39$ & $0.50 \pm 0.15$ \\
\hline & $(0.60-0.85)$ & $(0.46-0.82)$ & $(0.73-1.60)$ & $(0.32-0.67)$ \\
\hline \multirow[t]{2}{*}{$\mathrm{Si}$} & $2.32 \pm 0.92$ & $3.00 \pm 1.32$ & $3.41 \pm 3.08$ & $3.41 \pm 1.51$ \\
\hline & $(1.18-3.28)$ & $(1.98-5.35)$ & $(0.92-9.10)$ & $(1.21-5.28)$ \\
\hline \multirow[t]{2}{*}{$\mathrm{Sr}$} & $4.47 \pm 3.51$ & $6.11 \pm 4.06$ & $2.04 \pm 1.23$ & $8.84 \pm 2.16$ \\
\hline & $(0.74-8.66)$ & $(1.92-12.17)$ & $(0.85-4.22)$ & $(5.74-12.45)$ \\
\hline \multirow[t]{2}{*}{$\mathrm{Cd}$} & $0.33 \pm 0.13$ & - & $0.21 \pm 0.11$ & $0.19 \pm 0.2$ \\
\hline & $(0.13-0.43)$ & & $(0.07-0.33)$ & $(0.01-0.45)$ \\
\hline \multirow[t]{2}{*}{$\mathrm{Cu}$} & $0.98 \pm 0.86$ & $0.59 \pm 0.19$ & $0.62 \pm 0.22$ & $0.82 \pm 0.63$ \\
\hline & $(0.33-2.1)$ & $(0.38-0.9)$ & $(0.44-0.93)$ & $(0.52-2.1)$ \\
\hline \multirow[t]{2}{*}{$\mathrm{Ni}$} & $0.34 \pm 0.12$ & $0.44 \pm 0.14$ & $0.35 \pm 0.15$ & $0.49 \pm 0.15$ \\
\hline & $(0.2-0.53)$ & $(0.3-0.66)$ & $(0.25-0.64)$ & $(0.38-0.73)$ \\
\hline \multirow[t]{2}{*}{$\mathrm{Pb}$} & $0.19 \pm 0.87$ & $0.28 \pm 0.1$ & $0.41 \pm 0.325$ & - \\
\hline & $(0.09-0.3)$ & $(0.18-0.41)$ & $(0.06-1.00)$ & \\
\hline
\end{tabular}

et al. 2007). However, there is no consensus among the published reports. This may be due to different factors including location of capture and habitats, species, water concentration of elements, growth rate, metal accumulation, and detoxification mechanism (Marin-Guirao et al. 2008). In a recent study, the accumulation of trace elements in different organs of fish including muscle, skin, and gills of four edible fish species from the Rawal lake Reservoir, Pakistan, in a different season was described. The accumulation of trace metals in different organs of fish in pre-monsoon was lower than in 

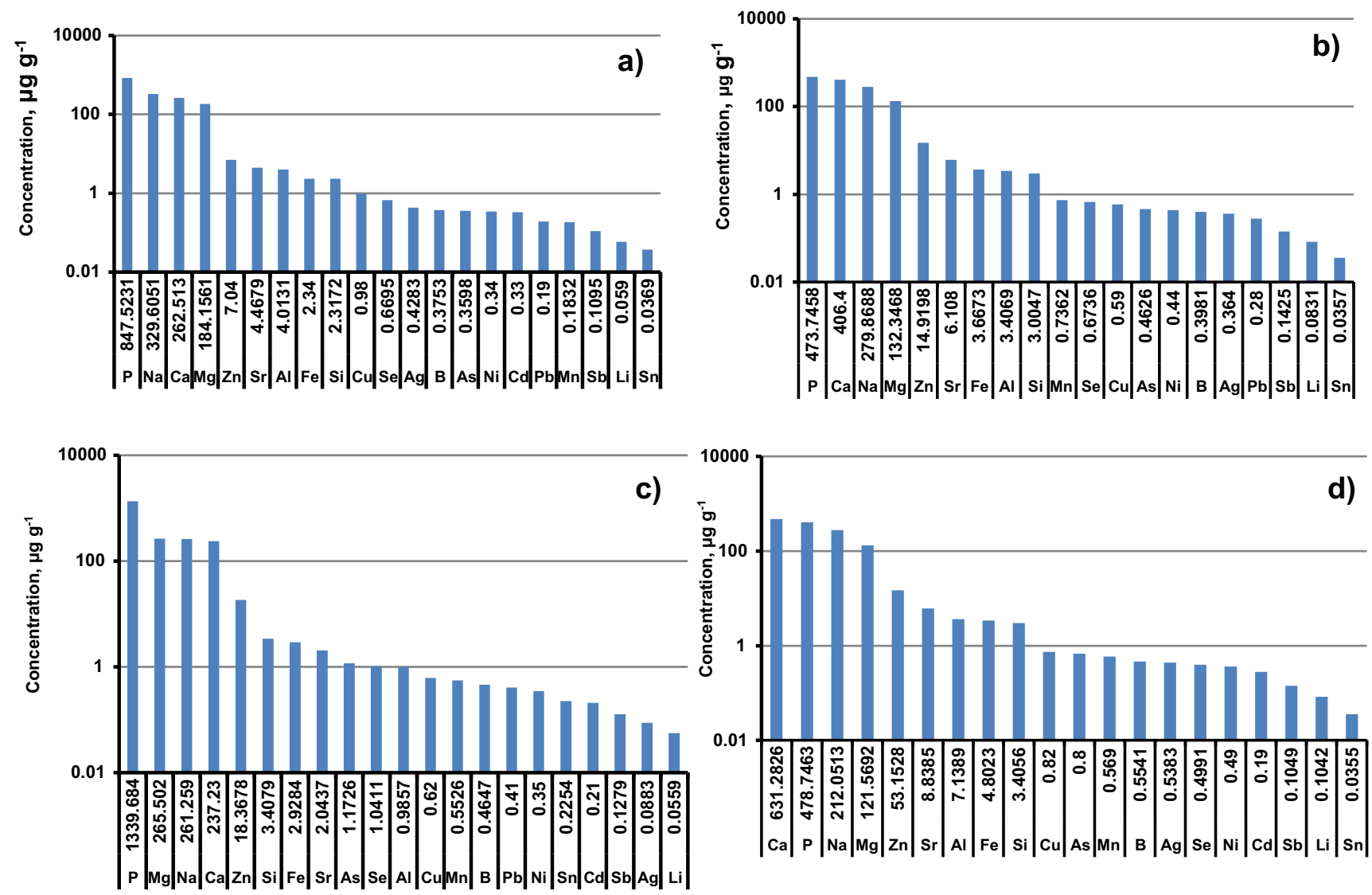

Fig. 2 Order of heavy metal, nutrient, and trace element concentrations in the muscle (a) and skin (b) tissues of O. ruber and muscle (c) and skin (d) tissues of $S$. guttatus

post-monsoon. In pre-monsoon season, the trace metals followed the order $\mathrm{Zn}>\mathrm{Pb}>\mathrm{Fe}>\mathrm{Cr}>\mathrm{Ni}>\mathrm{Mn}>\mathrm{Co}>\mathrm{Cu}$ $>\mathrm{Cd}>\mathrm{Li}$, while in the post-monsoon, the order was $\mathrm{Fe}>\mathrm{Pb}>$ $\mathrm{Cr}>\mathrm{Ni}>\mathrm{Zn}>\mathrm{Cu}>\mathrm{Co}>\mathrm{Mn}>\mathrm{Cd}>\mathrm{Li}$ (Malik et al. 2014).

The results of the present study showed that with the exception of $\mathrm{P}$ (with higher level in the muscle tissue of fish $(P<0.05$, Fig. 2a-d) there were no significant difference $(P>0.05)$ between heavy metal, macro, and trace element levels in the skin and muscle tissues of the $O$. ruber (Table 3) while $\mathrm{Ca}, \mathrm{Li}, \mathrm{Mg}$, $\mathrm{P}, \mathrm{Se}, \mathrm{Sn}, \mathrm{Sr}$, and $\mathrm{Zn}$ concentrations were significantly different $(P<0.05)$ in the skin and muscle tissues of $S$. guttatus (Table 3 ) $(\mathrm{Ca}, \mathrm{Li}, \mathrm{Sr}$, and $\mathrm{Zn}$ concentrations were higher in the skin tissue of fish, Fig. 2a-d). Our study showed S. guttatus contained significantly higher concentrations of $\mathrm{As}, \mathrm{Se}, \mathrm{Sn}$, and $\mathrm{P}$ in the muscle tissue and $\mathrm{Zn}$ in skin tissue $(P<0.05)$ compared to muscle and skin tissues of $O$. ruber (Table 3).

The elements such as iron, copper, zinc, and manganese are essential for biological systems such as enzymatic activities and functional and structural roles, whereas, elements like lead, cadmium, and arsenic are known as potentially toxic (Fernandes et al. 2008). The skin tissue of S. guttatus contained significantly higher concentrations $(P<0.05)$ of $\mathrm{Zn}$ and Ca compared to the muscle tissue of $S$. guttatus but the muscle tissue of $S$. guttatus contained significantly higher levels $(P<0.05)$ of $\mathrm{Mg}$, Se, and $\mathrm{P}$ compared to the skin tissue of $S$. guttatus. There were no significant differences $(P>0.05)$ between $\mathrm{Mn}, \mathrm{Fe}, \mathrm{Cu}$, and $\mathrm{Na}$ concentrations in the skin and muscle tissues of $S$. guttatus (Table 3 ). In the case of O. ruber, with the exception of $\mathrm{P}$ (with higher concentration in the muscle tissue of fish) $(P<0.05)$, there were no significant differences between $\mathrm{Se}, \mathrm{Zn}, \mathrm{Mn}, \mathrm{Ca}, \mathrm{Fe}, \mathrm{Cu}, \mathrm{Na}$, and $\mathrm{Mg}$ concentrations in the skin and muscle tissues of $O$. ruber (Table 3). The concentrations of Se and $\mathrm{P}$ in the muscle tissue of $S$. guttatus compared to $O$. ruber were higher and significantly different $(P<0.05)$ but no statistically significant differences $(P>0.05)$ were observed in the $\mathrm{Mn}, \mathrm{Ca}, \mathrm{Fe}, \mathrm{Cu}, \mathrm{Na}$, and $\mathrm{Mg}$ levels between $O$. ruber and S. guttatus tissues (both skin and muscle tissues); while the skin tissue of $S$. guttatus contained significantly higher concentration $(P<0.05)$ of $\mathrm{Zn}$ (Table 3). The difference in accumulation potential between skin and muscle of fish can be due to greater tendency of the element to react with the proteins that are present in the skin and muscle tissues of these fish (Uysal et al. 2008; VisnjicJeftic et al. 2010).

The similar pattern has ben extensively reported in several studies for different species (Brucka-Jastrzêbska et al. 2009; Jarić et al. 2011; Verep et al. 2007; Visnjic-Jeftic et al. 2010). In a report, the accumulation of heavy metals in the muscle 
Table 3 Comparison between the means of the element levels among the samples

\begin{tabular}{|c|c|c|c|c|c|c|c|c|}
\hline \multirow[t]{2}{*}{ Comparison } & \multicolumn{2}{|l|}{$\begin{array}{l}\text { Skin and muscle } \\
\text { of } O \text {. ruber }\end{array}$} & \multicolumn{2}{|c|}{$\begin{array}{l}\text { Skin and muscle of } \\
\text { S. guttatus }\end{array}$} & \multicolumn{2}{|c|}{$\begin{array}{l}\text { Skin of } O . \text { ruber and } \\
\text { skin of } S . \text { guttatus }\end{array}$} & \multicolumn{2}{|c|}{$\begin{array}{l}\text { Muscle of } O . \text { ruber and } \\
\text { muscle of } S . \text { guttatus }\end{array}$} \\
\hline & $\begin{array}{l}\text { Mean difference } \\
\text { (Std. Error) }\end{array}$ & $\mathrm{Sig}^{*}$ & $\begin{array}{l}\text { Mean difference } \\
\text { (Std. Error) }\end{array}$ & $\mathrm{Sig}^{*}$ & $\begin{array}{l}\text { Mean difference } \\
\text { Std. Error }\end{array}$ & Sig $^{*}$ & $\begin{array}{l}\text { Mean difference } \\
\text { Std. Error }\end{array}$ & $\mathrm{Sig}^{*}$ \\
\hline $\mathrm{Ag}$ & $0.064(0.259)$ & 0 & $-0.450(0.271)$ & 0 & $-0.174(0.351)$ & 0 & $0.340(0.166)$ & 0 \\
\hline $\mathrm{Al}$ & $0.606(1.578)$ & 0 & $-6.153(3.554)$ & 0 & $-3.732(2.511)$ & 0 & $3.027(2.082)$ & 0 \\
\hline As & $-0.102(0.081)$ & 0 & $0.372(0.197)$ & 0 & $-0.337(0.159)$ & 0 & $-0.812(0.142)$ & 1 \\
\hline B & $-0.022(0.118)$ & 0 & $-0.089(0.109)$ & 0 & $-0.155(0.117)$ & 0 & $-0.089(0.110)$ & 0 \\
\hline $\mathrm{Ca}$ & $-143.8(116.9)$ & 0 & $-394.05(93.9)$ & 1 & $-224.9(130.1)$ & 0 & $25.28(84.29)$ & 0 \\
\hline $\mathrm{Cd}$ & - & 0 & $0.026(0.112)$ & 0 & - & 0 & $0.115(0.086)$ & 0 \\
\hline $\mathrm{Cu}$ & $0.387(0.359)$ & 0 & $-0.148(0.271)$ & 0 & $-0.228(0.267)$ & 0 & $0.307(0.362)$ & 0 \\
\hline $\mathrm{Fe}$ & $-1.32731(0.78820)$ & 0 & $-1.873(1.123)$ & 0 & $-1.135(1.228)$ & 0 & $-0.588(0.612)$ & 0 \\
\hline $\mathrm{Li}$ & $-0.024(0.014)$ & 0 & $-0.048(0.010)$ & 1 & $-0.021(0.012)$ & 0 & $0.003(0.012)$ & 0 \\
\hline $\mathrm{Mg}$ & $51.81(24.894)$ & 0 & $143.9(41.09)$ & 1 & $10.77(24.35)$ & 0 & $-81.34(41.41)$ & 0 \\
\hline $\mathrm{Mn}$ & $-0.553(0.413)$ & 0 & $-0.016(0.196)$ & 0 & $0.167(0.416)$ & 0 & $-0.369(0.189)$ & 0 \\
\hline $\mathrm{Na}$ & $49.74(55.13)$ & 0 & $49.20(71.53)$ & 0 & $67.81(49.30)$ & 0 & $68.34(75.67)$ & 0 \\
\hline $\mathrm{Ni}$ & $-0.099(0.076)$ & 0 & $-0.140(0.087)$ & 0 & $-0.053(0.085)$ & 0 & $-0.011(0.078)$ & 0 \\
\hline $\mathrm{P}$ & $373.7(127.63)$ & 1 & $860.9(189.2)$ & 1 & $-5.00(133.29)$ & 0 & $-492.16(185.23)$ & 1 \\
\hline $\mathrm{Pb}$ & $-0.092(0.054)$ & 0 & - & 0 & - & 0 & $-0.218(0.137)$ & 0 \\
\hline $\mathrm{Sb}$ & $-0.033(0.015)$ & 0 & $0.023(0.021)$ & 0 & $0.037(0.017)$ & 0 & $-0.018(0.020)$ & 0 \\
\hline $\mathrm{Se}$ & $-0.004(0.066)$ & 0 & $0.542(0.170)$ & 1 & $0.174(0.081)$ & 0 & $-0.371(0.164)$ & 1 \\
\hline $\mathrm{Si}$ & $-0.687(0.657)$ & 0 & $0.002(1.400)$ & 0 & $-0.400(0.817)$ & 0 & $-1.090(1.313)$ & 0 \\
\hline $\mathrm{Sn}$ & $0.001(0.004)$ & 0 & $0.189(0.084)$ & 1 & $0.0002(0.004)$ & 0 & $-0.188(0.084)$ & 1 \\
\hline $\mathrm{Sr}$ & $-1.64(2.191)$ & 0 & $-6.794(1.015)$ & 1 & $-2.730(1.878)$ & 0 & $2.424(1.518)$ & 0 \\
\hline $\mathrm{Zn}$ & $-7.88(4.58)$ & 0 & $-34.78(12.92)$ & 1 & $-38.23(9.88)$ & 1 & $-11.327(9.509)$ & 0 \\
\hline
\end{tabular}

* Significance of 1 indicates that the difference of averages is significant at 0.05 ; Significance of 0 indicates that the difference of averages is not significant at 0.05

and bone of four fish species from the central Adriatic Sea were measured. Perugini et al. found no significant variations of heavy metal concentrations including $\mathrm{As}, \mathrm{Cd}, \mathrm{Cu}, \mathrm{Pb}, \mathrm{Zn}$, $\mathrm{Hg}$, and $\mathrm{Se}$ in the muscle of the examined species, but a significant difference was found for $\mathrm{Cd}, \mathrm{Pb}, \mathrm{Se}$, and As levels in the bones of the examined fish species (Perugini et al. 2014). In another study in the Pagasitikos Gulf in Greece, heavy metal concentrations in two fish species were determined. Significant differences were detected between two examined fish species' tissues concerning $\mathrm{Cu}$ and $\mathrm{Zn}$ levels (Giannakopoulou and Neofitou 2014). The essential trace element levels of $\mathrm{Fe}, \mathrm{Mn}, \mathrm{Cu}, \mathrm{Zn}$, and $\mathrm{Se}$ in the skin and muscle tissues of fish samples were found as $2.34-4.8 \mu \mathrm{g} / \mathrm{g}$ for $\mathrm{Fe}, 0.18-0.74 \mu \mathrm{g} / \mathrm{g}$ for $\mathrm{Mn}, 0.59-0.98 \mu \mathrm{g} / \mathrm{g}$ for $\mathrm{Cu}$, $7.04-53.15 \mu \mathrm{g} / \mathrm{g}$ for $\mathrm{Zn}$, and $0.5-1.04 \mu \mathrm{g} / \mathrm{g}$ for Se. Various previous studies have reported the essential element contents of different fish species samples. For example, in a study, the levels of $\mathrm{Cu}, \mathrm{Zn}$, and Se have been reported as 0.65-2.75. 38.8-93.4, and 0.19-0.85 $\mu \mathrm{g} / \mathrm{g}$, respectively (Tuzen 2009). In another report, the contents of these elements were found $1.10-2.50 \mu \mathrm{g} / \mathrm{g}$ for $\mathrm{Cu}, 7.57-34.4 \mu \mathrm{g} / \mathrm{g}$ for $\mathrm{Zn}$, and 0.96 $3.64 \mu \mathrm{g} / \mathrm{g}$ for Se (Tuzen and Soylak 2007).
Se is an essential element and acts as a regulator of thyroid hormone metabolism, antagonistic role to the toxicological effects of mercury, antioxidant, and anticarcinogenic (Khan et al. 1987). The Se concentration in our study was below the recommended toxicity threshold for aquatic biota (i.e., $10 \mu \mathrm{g} /$ $\mathrm{g}$ of dry weight) (Pyle et al. 2005). Ni is not an essential element but in a few trace levels, it may be useful to activate some enzyme systems. Chronic intake of $\mathrm{Ni}$ can be associated with increased risk of lung cancer (Expert Group on Vitamins and Minerals (EGVM) 2003). The level of $\mathrm{Ni}$ in the skin and muscle tissues of $S$. guttatus compared to the skin and muscle tissues of $O$. ruber were not significantly different $(P>0.05)$; also, there was no significant difference $(P>0.05)$ between the skin tissue and muscle tissue of every fish (Table 3 ). Because of the unknown metabolic function in organism, $\mathrm{Sr}$ is not an essential element, but it can be used as a marker to differentiate between meat and fish due to the fact that its level is noticeably higher in fish than in meat (Carvalho et al. 2005). The concentration of $\mathrm{Sr}$ was significantly higher $(P<0.05)$ in the skin tissue compared to the muscle tissue of $S$. guttatus but no significant difference $(P>0.05)$ was found in the $\mathrm{Sr}$ concentration between the skin and muscle tissues of $O$. ruber. 
Also, no statistically significant differences $(P>0.05)$ were observed in the $\mathrm{Sr}$ concentration in the muscle tissues of fish as well as their skin tissues (Table 3). The concentrations of $\mathrm{Al}, \mathrm{Si}, \mathrm{B}$, and $\mathrm{Li}$ in the skin and muscle tissues of $S$. guttatus compared to the skin and muscle tissues of $O$. ruber were not significantly different $(P>0.05)$. Also, there were no significant differences $(P>0.05)$ between the $\mathrm{Al}, \mathrm{Si}, \mathrm{B}$, and $\mathrm{Li}$ concentrations in the skin and muscle tissues of $O$. ruber, but the skin tissue of $S$. guttatus contained significantly a higher level of Li compared to its muscle tissue.

Some elements such as $\mathrm{Ag}, \mathrm{Cd}, \mathrm{Pb}, \mathrm{Sn}, \mathrm{Sb}$, and As, classify as toxic elements and have no metabolic function but can be harmful for human health, even at low levels, if ingested over a long time period (Somers 1974). The toxic element levels of
$\mathrm{Ag}, \mathrm{As}, \mathrm{Cd}, \mathrm{Sb}, \mathrm{Pb}$, and $\mathrm{Sn}$ in the skin and muscle tissues of fish samples were found as $0.09-0.54 \mu \mathrm{g} / \mathrm{g}$ for $\mathrm{Ag}, 0.36$ $1.17 \mu \mathrm{g} / \mathrm{g}$ for As, $0.19-0.33 \mu \mathrm{g} / \mathrm{g}$ for Cd, $0.1-0.14 \mu \mathrm{g} / \mathrm{g}$ for $\mathrm{Sb}, 0.19-0.41 \mu \mathrm{g} / \mathrm{g}$ for $\mathrm{Pb}$, and $0.04-0.23 \mu \mathrm{g} / \mathrm{g}$ for $\mathrm{Sn}$. In a study, the toxic element levels of $\mathrm{Pb}$ and $\mathrm{Cd}$ in fish species harvested off from the Black and Aegean Seas were found in the ranges of $0.33-0.93$ and $0.45-0.9 \mu \mathrm{g} / \mathrm{g}$, respectively (Uluozlu et al. 2007). Fallah et al. also have reported the toxic levels of $\mathrm{Pb}, \mathrm{Cd}$, and $\mathrm{As}$ in edible tissues of farmed and wild rainbow trout in the ranges of $0.99-5.32,0.00-1.21$, and $0.00-3.56 \mu \mathrm{g} / \mathrm{g}$, respectively (Fallah et al. 2011). Another study has reported the levels of $\mathrm{Pb}$ and $\mathrm{Cd}$ in fish species harvested off from the Tokat Lake in the range of 0.7-2.4 and $0.1-1.2 \mu \mathrm{g} / \mathrm{g}$, respectively (Mendil et al. 2005).

Table 4 The estimated daily intakes of elements for the fish sample and comparison with recommended safety guidelines

\begin{tabular}{|c|c|c|c|c|c|c|c|c|c|}
\hline \multirow{3}{*}{ Analytes } & \multicolumn{4}{|c|}{ EDI (Estimated daily intake) } & \multicolumn{4}{|c|}{ EWI (Estimated weekly intake) } & \multirow{3}{*}{$\begin{array}{l}\text { PTWI }^{\mathrm{c}} \text { or PMTDI } \\
\mu \mathrm{d} / \mathrm{kg} \mathrm{BW} / \text { day }\end{array}$} \\
\hline & \multicolumn{2}{|l|}{ O. ruber } & \multicolumn{2}{|c|}{ S. guttatus } & \multicolumn{2}{|l|}{ O. ruber } & \multicolumn{2}{|c|}{ S. guttatus } & \\
\hline & $\mu \mathrm{g} / \mathrm{kg}^{\mathrm{a}}$ & $\mu \mathrm{g} / \mathrm{kg} \mathrm{BW} /$ day $^{\mathrm{b}}$ & $\mu \mathrm{g} / \mathrm{kg}^{\mathrm{a}}$ & $\mu \mathrm{g} / \mathrm{kg} \mathrm{BW} /$ day $^{\mathrm{b}}$ & $\mu \mathrm{g} / \mathrm{kg}^{\mathrm{a}}$ & $\mu \mathrm{g} / \mathrm{kg} \mathrm{BW} /$ day $^{\mathrm{b}}$ & $\mu \mathrm{g} / \mathrm{kg}^{\mathrm{a}}$ & $\mu \mathrm{g} / \mathrm{kg} \mathrm{BW} /$ day $^{\mathrm{b}}$ & \\
\hline \multicolumn{10}{|c|}{ Toxic elements } \\
\hline $\mathrm{Ag}$ & 9.03 & 0.150 & 1.89 & 0.031 & 63.21 & 1.053 & 13.23 & 0.220 & \\
\hline AS & 7.56 & 0.126 & 24.57 & 0.409 & 52.92 & 0.882 & 171.99 & 2.866 & 15 \\
\hline $\mathrm{Cd}$ & 6.93 & 0.115 & 4.41 & 0.073 & 48.51 & 0.808 & 30.87 & 0.514 & 1 \\
\hline $\mathrm{Sb}$ & 2.31 & 0.038 & 2.73 & 0.045 & 16.17 & 0.269 & 19.11 & 0.318 & $6^{*}$ \\
\hline $\mathrm{Pb}$ & 3.99 & 0.066 & 8.61 & 0.143 & 27.93 & 0.465 & 60.27 & 1.004 & 3.6 \\
\hline $\mathrm{Sn}$ & 0.84 & 0.014 & 4.83 & 0.080 & 5.88 & 0.098 & 33.81 & 0.563 & $220^{\ddagger}$ \\
\hline \multicolumn{10}{|c|}{ Essential elements } \\
\hline $\mathrm{Ca}$ & 5512.7 & 91.87 & 4981.8 & 83.03 & $38,588.9$ & 643.2 & $34,872.8$ & 581.2 & \\
\hline $\mathrm{Cu}$ & 20.58 & 0.343 & 13.02 & 0.217 & 144.06 & 2.401 & 91.14 & 1.519 & $50-500 ; 160^{\dagger}$ \\
\hline $\mathrm{Fe}$ & 49.14 & 0.819 & 61.53 & 1.025 & 343.98 & 5.733 & 430.71 & 7.178 & \\
\hline $\mathrm{Mg}$ & 3867.3 & 64.45 & 5575.5 & 92.92 & $27,071.5$ & 451.19 & $39,028.5$ & 650.47 & \\
\hline $\mathrm{Mn}$ & 3.78 & 0.063 & 11.55 & 0.192 & 26.46 & 0.441 & 80.85 & 1.347 & 200 or $150^{\ddagger}$ \\
\hline $\mathrm{Na}$ & 6921.81 & 115.36 & 5486.46 & 91.441 & $48,452.67$ & 807.54 & $38,405.2$ & 640.08 & \\
\hline $\mathrm{P}$ & $17,797.9$ & 296.63 & $28,133.3$ & 468.9 & $124,585.4$ & 2076.4 & 196,933 & 3282.2 & \\
\hline $\mathrm{Zn}$ & 147.84 & 2.464 & 385.77 & 6.429 & 1034.88 & 17.248 & 2700.39 & 45.006 & $300-1000$ \\
\hline $\mathrm{Se}$ & 14.07 & 0.234 & 21.84 & 0.364 & 98.49 & 1.641 & 152.88 & 2.548 & $5^{\dagger}$ \\
\hline \multicolumn{10}{|c|}{ Nonessential } \\
\hline $\mathrm{Ni}$ & 7.14 & 0.119 & 7.35 & 0.122 & 49.98 & 0.833 & 51.45 & 0.857 & $4.3^{t}$ \\
\hline $\mathrm{Sr}$ & 93.87 & 1.564 & 42.84 & 0.714 & 657.09 & 10.955 & 299.88 & 4.998 & \\
\hline $\mathrm{Al}$ & 84.21 & 1.403 & 20.79 & 0.346 & 589.47 & 9.824 & 145.53 & 2.425 & 143 \\
\hline
\end{tabular}

${ }^{\text {a }}$ Estimated daily intake ( $\mu \mathrm{g} /$ day)

${ }^{\mathrm{b}}$ Estimated daily intake ( $\mu \mathrm{g} / \mathrm{day} / 60 \mathrm{~kg}$ body weight)

${ }^{\mathrm{c}}$ Provisional tolerable weekly intake ( $\mu \mathrm{g} / \mathrm{week} / \mathrm{kg}$ body weight)

${ }^{\mathrm{d}}$ Provisional maximum tolerable daily intake ( $\mu \mathrm{g} / \mathrm{day} / \mathrm{kg}$ body weight)

\# The numerical values shown are the tolerable daily intake for a $60 \mathrm{~kg}$ person derived from PTWls or PMTDls recommended by JECFA (WHO 2006) unless mentioned otherwise

* TDI derived by WHO (WHO 2003)

‡Expert group on vitamins and minerals-guidance level (EVM 2003)

${ }^{\dagger}$ Expert group on vitamins and minerals—safe upper level (EVM 2003) 
The concentrations of $\mathrm{Sb}$ and $\mathrm{Ag}$ in the muscle and skin tissues of $S$. guttatus were not significantly different $(P>0.05)$ compared to the muscle and skin tissues of $O$. ruber. Also, the concentrations of $\mathrm{Cd}$ and $\mathrm{Pb}$ in the muscle tissues of $S$. guttatus and $O$. ruber were not significantly different $(P>0.05)$. There were no significant difference $(P>0.05)$ between the concentrations of $\mathrm{Ag}, \mathrm{Sb}$, and $\mathrm{As}$ in the skin and muscle tissues of every examined fish while the muscle tissue of $S$. guttatus contained significantly higher concentrations $(P<0.05)$ of As and $\mathrm{Sn}$ compared to the muscle tissue of O. ruber. Also, results showed that the muscle tissue of $S$. guttatus had significantly higher levels $(P<0.05)$ of Sn compared to its skin tissue. In a research, Mendil et al. measured heavy metal contents in four commercially fish species from the Black Sea. The concentrations of all examined trace metals such as $\mathrm{Fe}, \mathrm{Zn}, \mathrm{Pb}, \mathrm{Cr}$, $\mathrm{Mn}, \mathrm{Cu}, \mathrm{Cd}$, and $\mathrm{Co}$ depended on the fish species. The metals followed the trend $\mathrm{Fe}>\mathrm{Zn}>\mathrm{Mn}>\mathrm{Cu}>\mathrm{Cr}>\mathrm{Pb}>\mathrm{Co}>\mathrm{Cd}$ (Mendil et al. 2010). In another study, significant difference was observed between two examined fish species tissues in term of Cd concentration (Giannakopoulou and Neofitou 2014).

All examined heavy metals and toxic elements were found to be lower than the maximum level allowed in food that is recommended by WHO (WHO 1999). Similar acceptable concentrations of heavy metal contents in different fish species have been reported (Dobaradaran et al. 2010; Perugini et al. 2014; Saei-Dehkordi and Fallah 2011; Uysal et al. 2008). Though Mendil et al. have reported that the levels of lead and cadmium in the examined fish from the Black Seas were higher than the recommended limits while the concentrations of other examined metals were acceptable (Mendil et al. 2010). In another study, the concentrations of $\mathrm{Ni}, \mathrm{Cr}$, and $\mathrm{Pb}$ in the muscle of all examined fish species were higher than the WHO guideline values (Malik et al. 2014).

Dietary exposure assessment for the toxic elements and other elements through fish consumption was carried out by evaluating daily and weekly intakes. According to a report of the Fishery Statistics of Iran (Annual Fishery Statistics of Iran 2010), the fish consumption per day and week in Iran has been considered as 21 and $147 \mathrm{~g}$, respectively. The estimated daily/ weekly intakes (EDI/EWI) due to consumption of the muscle of $O$. ruber and $S$. guttatus for an adult with $60-\mathrm{kg}$ body weight are demonstrated in Table 4 and have been compared with the guidelines. All calculated EDI and EWI values revealed that the dietary exposure to toxic elements due to the consumption of these fish could be considered safe. EDI/EWI values for arsenic were calculated due to the total arsenic not inorganic arsenic. It is well known that most arsenic in fish is organic arsenic which is the less toxic form of arsenic. It has been reported that the percentage of inorganic arsenic in fish is between 0.02 and $11 \%$ (Muñoz et al. 2000) whereas the WHO set a $3000 \mu \mathrm{g}$ for a subject of $60 \mathrm{~kg}$ as the maximum acceptable daily load for arsenic (FAO/WHO 1989). Results indicated that EDI/EWI values of examined toxic elements in the present study could be considered safe in comparison to the guidelines limits, so there is no health threatening concern due to consumption of $S$. guttatus and $O$. ruber in Iran. In another study in Iran, the estimated daily and weekly intakes of zinc, lead, and copper via fish consumption flesh from the Iranian market were below the established values by WHO (Saei-Dehkordi and Fallah 2011).

\section{Conclusions}

The results of the present study provides important information on the toxic, macro, and trace element accumulation in the skin and muscles tissues of $O$. ruber and $S$. guttatus harvested commercially off the Persian Gulf. Concentrations of some elements ( $\mathrm{Ca}, \mathrm{Li}, \mathrm{Mg}, \mathrm{P}, \mathrm{Se}, \mathrm{Sn}, \mathrm{Sr}$, and $\mathrm{Zn})$ were significantly different between the skin and muscle tissues of the S. guttatus but with the exception of P, there were no significant difference between the element concentrations in the skin and muscle tissues of $O$. ruber. $S$. guttatus contained significantly higher levels of $\mathrm{As}, \mathrm{Sn}, \mathrm{Se}$, and $\mathrm{P}$ in the muscle tissue and $\mathrm{Zn}$ in the skin tissue compared to the muscle and skin tissues of $O$. ruber. The estimated daily and weekly intakes of toxic elements such as $\mathrm{As}, \mathrm{Cd}, \mathrm{Sb}, \mathrm{Pb}$, and $\mathrm{Sn}$ showed that the safety of dietary intakes of these elements via consumption of these two important commercial species should be considered acceptable. Finally, in view of the potential contamination by the oil activities near the fishing points, continuous and permanent monitoring in this region is highly recommended.

Acknowledgments The authors are grateful to the Bushehr University of Medical Science for financial support.

\section{References}

Alibabic V, Vahcic N, Bajramovic M (2007) Bioaccumulation of metals in fish of Salmonidae family and the impact on fish meat quality. Environ Monit Assess 131:349-364. doi:10.1007/s10661-0069480-6

Annual Fishery Statistics of Iran (2010) Consumption of fish in Iran. Ministry of Agriculture: pp 36-40.

Brucka-Jastrzêbska E, Kawczuga D, Rajkowska M, Protasowicki M (2009) Levels of microelements [Cu, $\mathrm{Zn}, \mathrm{Fe}]$ and macroelements $[\mathrm{Mg}, \mathrm{Ca}]$ in freshwater fish. J Elem 14:437-447

Canli M, Atli G (2003) The relationships between heavy metal (Cd, Cr, $\mathrm{Cu}, \mathrm{Fe}, \mathrm{Pb}, \mathrm{Zn}$ ) levels and the size of six Mediterranean fish species. Environ Pollut 121:129-136. doi:10.1016/S0269-7491(02)00194-X

Carvalho ML, Santiago S, Nunes ML (2005) Assessment of the essential element and heavy metal content of edible fish muscle. Anal Bioanal Chem 382:426-432. doi:10.1007/s00216-004-3005-3

Collette BB, Nauen CE (1983) Scombrids of the word: an annoted and illustrated catalogue of tunas, mackerels, bonitos and related species known to date. FAO Species Catalog 2 
Dobaradaran S, Naddafi K, Nazmara S, Ghaedi H (2010) Heavy metals $(\mathrm{Cd}, \mathrm{Cu}, \mathrm{Ni}$ and $\mathrm{Pb})$ content in two fish species of Persian Gulf in Bushehr Port. Iran Afr J Biotechnol 9:6191-6193

Dobaradaran S, Abadi DRV, Mahvi AH, Javid A (2011) Fluoride in skin and muscle of two commercial species of fish harvested off the Bushehr Shores of the Persian Gulf fluoride 44:143-146

Dural M, Goksu MZL, Ozak AA (2007) Investigation of heavy metal levels in economically important fish species captured from the Tuzla lagoon. Food Chem 102:415-421. doi:10.1016/j.foodchem. 2006.03.001

EGVM (Expert Group on Vitamins and Minerals) (2003) Risk assessment: nickel, http://archive.food.gov.uk/dept_health/pdf/evmpdf/ evm9924.pdf

Fallah AA, Saei-Dehkordi SS, Nematollahi A, Jafari T (2011) Comparative study of heavy metal and trace element accumulation in edible tissues of farmed and wild rainbow trout (Oncorhynchus mykiss) using ICP-OES technique. Microchem J 98:275-279. doi: 10.1016/j.microc.2011.02.007

FAO/WHO (1989) EValuation of certain food AdditiVes and contaminants; technical report series 759. World Health Organization, Geneva

Fernandes C, Fontainhas-Fernandes A, Cabral D, Salgado MA (2008) Heavy metals in water, sediment and tissues of Liza saliens from Esmoriz-Paramos Lagoon. Port Environ Monit Assess 136:267275. doi:10.1007/s10661-007-9682-6

Fischer W, Bianchi G (1984) FAO species identification sheets for fishery purposes. Western Indian Ocean (Fishing Area 51) 4

Giannakopoulou L, Neofitou C (2014) Heavy metal concentrations in Mullus barbatus and Pagellus erythrinus in relation to body size, gender, and seasonality. Environ Sci Pollut Res 21:7140-7153

Jarić I, Višnjić-Jeftić Ž, Cvijanović G, Gačić Z, Jovanović L, Skorić S, Lenhardt M (2011) Determination of differential heavy metal and trace element accumulation in liver, gills, intestine and muscle of sterlet (Acipenser ruthenus) from the Danube River in Serbia by ICP-OES. Microchem J 98:77-78

Kagi JH, Schaffer A (1988) Biochemistry of metallothionein. Biochem 27:8509-8515

Khan AH, Ali M, Biaswas SK, Hadi DA (1987) Trace-elements in marine fish from the Bay of Bengal. Sci Total Environ 61:121-130. doi:10. 1016/0048-9697(87)90362-7

Malik RN, Hashmi MZ, Huma Y (2014) Heavy metal accumulation in edible fish species from Rawal Lake Reservoir. Pak Environ Sci Pollut Res 21:1188-1196

Mansour SA, Sidky MM (2002) Ecotoxicological studies. 3. Heavy metals contaminating water and fish from fayoum governorate. Egypt Food Chem 78:15-22. doi:10.1016/S0308-8146(01)00197-2

Marin-Guirao L, Lloret J, Marin A (2008) Carbon and nitrogen stable isotopes and metal concentration in food webs from a miningimpacted coastal lagoon. Sci Total Environ 393:118-130. doi:10. 1016/j.scitotenv.2007.12.023

Mendil D, Uluözlü ÖD, Hasdemir E, Tüzen M, Sarı H, Suiçmez M (2005) Determination of trace metal levels in seven fish species in lakes in Tokat. Turk Food Chem 90:175-179. doi:10.1016/j. foodchem.2004.03.039

Mendil D, Demirci Z, Tuzen M, Soylak M (2010) Seasonal investigation of trace element contents in commercially valuable fish species from the Black sea. Turk Food Chem Toxicol 48:865-870. doi:10.1016/j. fct.2009.12.023

Muñoz O et al (2000) Total and inorganic arsenic in fresh and processed fish products. J Agric Food Chem 48:4369-4376
Olojo EAA, Olurin KB, Mbaka G, Oluwemimo AD (2005) Histopathology of the gill and liver tissues of the African catfish Clarias gariepinus exposed to lead. Afr J Biotechnol 4:117-122

Perugini M, Visciano P, Manera M, Zaccaroni A, Olivieri V, Amorena M (2014) Heavy metal (As, Cd, Hg, Pb, Cu, Zn, Se) concentrations in muscle and bone of four commercial fish caught in the central Adriatic Sea. Italy Environ Monit Assess 186:2205-2213

Pyle GG, Rajotte JW, Couture P (2005) Effects of industrial metals on wild fish populations along a metal contamination gradient. Ecotox Environ Safe 61:287-312. doi:10.1016/j.econenv.2004.09.003

Saei-Dehkordi SS, Fallah AA (2011) Determination of copper, lead, cadmium and zinc content in commercially valuable fish species from the Persian Gulf using derivative potentiometric stripping analysis. Microchem J 98:156-162. doi:10.1016/j.microc.2011.01.001

Santos LFP, Trigueiro INS, Lemos VA, Furtunato DMD, Cardoso RDV (2013) Assessment of cadmium and lead in commercially important seafood from Sao Francisco do Conde, Bahia. Brazil Food Control 33:193-199. doi:10.1016/j.foodcont.2013.02.024

Somers E (1974) Toxic potential of trace-metals in foods. Rev J Food Sci 39:215-217. doi:10.1111/j.1365-2621.1974.tb02860.x

Tüzen M (2003) Determination of heavy metals in fish samples of the middle Black Sea (Turkey) by graphite furnace atomic absorption spectrometry. Food Chem 80:119-123

Tuzen M (2009) Toxic and essential trace elemental contents in fish species from the Black Sea. Turk Food Chem Toxicol 47:17851790. doi:10.1016/j.fct.2009.04.029

Tuzen M, Soylak M (2007) Determination of trace metals in canned fish marketed in Turkey. Food Chem 101:1378-1382. doi:10.1016/j. foodchem.2006.03.044

Tuzen M, Karaman I, Citak D, Soylak M (2009) Mercury (II) and methyl mercury determinations in water and fish samples by using solid phase extraction and cold vapour atomic absorption spectrometry combination. Food Chem Toxicol 47:1648-1652. doi:10.1016/j.fct. 2009.04.024

Uluozlu OD, Tuzen M, Mendil D, Soylak M (2007) Trace metal content in nine species of fish from the Black and Aegean Seas. Turk Food Chem 104:835-840. doi:10.1016/j.foodchem.2007.01.003

Uysal K, Emre Y, Köse E (2008) The determination of heavy metal accumulation ratios in muscle, skin and gills of some migratory fish species by inductively coupled plasma-optical emission spectrometry (ICP-OES) in Beymelek Lagoon (Antalya/Turkey). Microchem J 90:67-70. doi:10.1016/j.microc.2008.03.005

Verep B, Akin S, Mutlu C, Ertugral B, Apaydin G, Cevik U (2007) Assesment of trace elements in rainbow trout (Oncorhynchus mykiss) cultured in the marine aquaculture cages on the black sea coast. Fresenius Environ Bull 16:1005

Visnjic-Jeftic Z, Jaric I, Jovanovic L, Skoric S, Smederevac-Lalic M, Nikcevic M, Lenhardt M (2010) Heavy metal and trace element accumulation in muscle, liver and gills of the Pontic shad (Alosa immaculata Bennet 1835) from the Danube River (Serbia). Microchem J 95:341-344. doi:10.1016/j.microc.2010.02.004

WHO (1999) Food safety issues associated with product from aquaculture. WHO Technical Report Series 883

WHO (2003) Chemical hazards in drinking water WHO Guidelines for Drinking-water Quality

WHO (2006) Sixty-seventh meeting of the joint FAO/WHO Expert Committee on Food Additives; 20-29 June 2006, Rome, http:// www.who.int/ipcs/food/jecfa/summaries/summary67pdf

Yilmaz F, Ozdemir N, Demirak A, Tuna AL (2007) Heavy metal levels in two fish species Leuciscus cephalus and Lepomis gibbosus. Food Chem 100:830-835. doi:10.1016/j.foodchem.2005.09.020 